\title{
CLASSIFICATION OF UNMANNED AERIAL VEHICLES AND ITS SIGNIFICANCE FOR CRIMINALISTIC PRACTICE
}

\section{Bilous $\boldsymbol{V}$. $\boldsymbol{V}$.}

The paper is devoted to the clarification of the notion and to the development of a generalized classification of unmanned aerial vehicles (UAV) which is necessary to substantiate the choice of those or other types of UAV for their use in the activity of the criminal justice bodies. The need to take into account the proposed classification in the formulation of criminalistic requirements for tactical and technical data UAV and systems, unmanned aircraft complexes and the characteristics of the target outfit, compliance with which is more responsive to meet the urgent needs of the field criminalistics is substantiated. The negative tendencies resulting from the use of unmanned aerial technologies without proper scientific support in the practice of the law enforcement bodies are revealed. It's noted that all technical and tactical UAV data are in correlation relationship and interdependence that allow to attribute them to definite classificational group and, having established the presence of particular characteristics, to suggest the parameters of others with a high degree of probability. Not taking into account of this in the case when the UAV is an instrument of crime, leads to improper establishing of aircraft apparatus group belongingness and may cause errors in establishing the control point location of UAV and its operator. Another negative tendency is in the use of such UAV by the law enforcement agencies in carrying out urgent tasks which are inappropriate. Taking into account foreign and domestic experience, UAV usage directions in order to improve the quality and efficiency of the work on detection, investigation, judicial consideration and prevention of the criminal offenses during realization and maintenance of the wide range of investigation (search), covert investigative (search), judicial and of procedural actions from the air are marked.

Keywords: criminal investigation technique, informational technologies, unmanned aerial vehicles and systems, unmanned aviation complexes, classification of unmanned aerial vehicles. міналістики та судової експертології Харківського національного університету внутрішніх справ, кандидат юридичних наук, доцент

\section{ОСОБЛИВОСТІ РОЗСЛІДУВАННЯ ЗЛОЧИНІВ, ЩО ВЧИНЯЮТЬСЯ СЛУЖБОВИМИ АБО ІНШИМИ ОСОБАМИ ШЛЯХОМ НЕВИКОНАННЯ РІШЕНЬ ОРГАНІВ ПРАВОСУДДЯ}

Визначено основні особливості розслідування злочинів, щцо вчиняються службовими або іншими особами шляхом невиконання рішень органів правосуддя. Розкрито типові слідчі ситуачї початкового етапу розслідування таких злочинів, подано алгоритми дій слідчого. Розглянуто тактичні особливості проведення окремих слідчих (розшукових) дій та питання взаємодії слідчого з правоохоронними органами.

(C) Книженко С. О., 2016 
Ключові слова: невиконання рімень органів правосуддя, злочини проти правосуддя, розслідування злочинів, криміналістична методика.

Створення правової держави передбачає не тільки розвиток системи судових та інших правоохоронних органів, але й захист правосуддя від злочинних посягань. Невиконання рішень органів правосуддя негативно впливає на авторитет як судової влади, так і правоохоронної системи в цілому, оскільки в цьому разі, як відзначено у юридичній літературі, не досягається кінцева мета правосуддя - захист інтересів громадян і реальне поновлення їх порушених прав ${ }^{1}$.

Зауважимо, що ми підтримуємо позицію тих дослідників, які до органів правосуддя відносять суди, оперативні підрозділи, органи досудового розслідування, прокуратури та органи, які відають виконанням судових рішень ${ }^{2}$.

Одним із видів злочинів проти правосуддя є злочини, що вчиняються службовими або іншими особами шляхом невиконання рішень органів правосуддя (невиконання судового рішення (ст. 382 КК України); незаконні дії щодо майна, на яке накладено арешт, заставленого майна або майна, яке описано чи підлягає конфіскації (ст. 388 КК України) 3 . На сьогодні ці злочини набули значного поширення на території нашої держави. Статистичні дані Генеральної прокуратури України, Міністерства внутрішніх справ України свідчать про те, що за останні п’ять років кількість досліджуваних злочинів зросла більше ніж удвічі ${ }^{4}$. Водночас діяльність правоохоронних органів щодо припинення, розкриття та розслідування визначених злочинів проти правосуддя $є$ недостатньо ефективною. Аналіз судово-слідчої практики вказує на те, що слідчі мають певні труднощі в розслідуванні таких злочинів, особливо на початковому етапі.

На сьогодні в юридичній літературі більша частина робіт присвячена дослідженню кримінально-правових і кримінологічних аспектів злочинів проти правосуддя, у тому числі й злочинів, що вчиняються службовими або іншими особами шляхом невиконання рішень органів правосуддя. Так, кримінально-правові та кримінологічні аспекти злочинів проти правосуддя досліджували М. П. Барабанов, А. В. Дмитров, К. Р. Ідрісов, В. С. Ква-

1 Див.: Романюк Я. Невиконання судових рішень нівелює кінцеву мету правосуддя - захист інтересів громадян і реальне поновлення їхніх порушених прав [Електронний ресурс] / Я. Романюк // Інформ. сервер Верхов. Суду України. — Режим доступу : http://www.scourt.gov.ua/clients/vs.nsf/.

Див.: Навроцький В. О. Злочини проти правосуддя : лекції для студ. юрид. ф-ту / В. О. Навроцький. - Львів : Юрид. ф-тет Львів. держ. ун-ту ім. Івана Франка, 1997. - С. 6.

3 Див.: Книженко С. О. Криміналістична класифікація злочинів проти правосуддя / С. О. Книженко // Право і безпека. — 2013. - № 1(48). - С. 118.

4 Див.: Стан та структура злочинності в Україні (2009-2010 рр.) [Електронний ресурс] // Офіц. веб-портал МВС України. - Режим доступу : http://mvs.gov.ua/; Єдиний звіт про кримінальні правопорушення по державі за січень-грудень 2015 р. [Електронний ресурс] // Офіц. веб-портал Ген. прокуратури України. — Режим доступу : http://www.gp.gov.ua/. 
шис, О. О. Коробейніков, М. Ф. Костюк, Л. В. Лобанів, А. Я. Марков, С. С. Мірошниченко, В. О. Навроцький, В. К. Сауляк, В. В. Смірнов, А. П. Стуканов та ін.

У криміналістиці предметом розгляду були проблеми розслідування лише окремих видів злочинів проти правосуддя. Зокрема, дослідження С. О. Кутякіна зі співавторами, А. С. Ямашкіна присвячені методиці розслідування втеч із місць позбавлення волі ${ }^{1}$, В. Г. Лісогор вивчав проблеми криміналістичного забезпечення збереження таємниці досудового слідства ${ }^{2}$. У роботах Ю. П. Адамова, О. Р. Ратінова опрацьовані основні положення методики розслідування надання неправдивих свідчень ${ }^{3}$. Наукові праці Д. Ю. Четвертака присвячені розслідуванню приховування злочинів ${ }^{4}$.

Криміналістичні аспекти розслідування злочинів, що вчиняються службовими або іншими особами шляхом невиконання рішень органів правосуддя, на жаль, майже не досліджені. Така ситуація в підсумку негативно впливає на якісний рівень професійної підготовки слідчих, що призводить до зниження ефективності протидії цим кримінальним правопорушенням.

Викладене свідчить про актуальність розроблення методики розслідування злочинів, що вчиняються службовими або іншими особами шляхом невиконання рішень органів правосуддя.

Meта статті полягає в розкритті основних положень розслідування злочинів проти правосуддя, що вчиняються службовими або іншими особами шляхом невиконання рішень органів правосуддя.

Криміналістична методика в юридичній літературі визначається як система наукових положень і розроблених на ії підставі рекомендацій із розкриття та розслідування окремих видів злочинів ${ }^{5}$.

Відзначимо, що методика розслідування злочинів, які вчиняються службовими або іншими особами шляхом невиконання рішень органів правосуддя, має свої особливості, котрі, насамперед, виявляються в слідчих ситуаціях початкового етапу розслідування. Так, на вид і зміст слідчих ситуацій досліджуваних злочинів впливають сфера, у якій не виконується рішення

${ }^{1}$ Див.: Кутякин C. А. Криминалистическая характеристика побегов из учреждений уголовно-исполнительной системы : учеб. пособие / С. А. Кутякин, Н. И. Ткаченко, Э. В. Лядов. - Рязань : Акад. права и управ. Фед. службы исполнения наказания, 2005. - 165 с.; Ямашкин А. С. Методика расследования побегов из мест лишения свободы : монография / А. С. Ямашкин. - М. : Юрлитинформ, 2012. 208 c.

2 Див.: Лісогор В. Г. Криміналістичне забезпечення збереження таємниці досудового слідства : дис. ... канд. юрид. наук : 12.00.09 / В. Г. Лісогор. — К., 2003. $101 \mathrm{c}$.

3 Див.: Ратинов А. Р. Лжесвидетельство (Происхождение, предотвращение и разоблачение ложных показаний) / А. Р. Ратинов, Ю. П. Адамов. - М. : Юрлитинформ, 1976. - 135 с.

4 Див.: Четвертак Д. Характеристика обстановки вчинення приховування злочинів / Д. Четвертак // Нац. юрид. журнал: теория и практика. — 2015. — № 3(13). С. $85-88$.

5 Див.: Криминалистика : учебник : в 3 ч. Ч. 3: Криминалистическая методика / под ред. Г. Н. Мухина. - 2-е изд., испр. - Минск. : Акад. МВД, 2010. - С. 3. 
органу правосуддя, характер злочинних дій, наявність протидії з боку підозрюваного.

Криміналісти поділяють слідчі ситуації на прості і складні; типові та специфічні; початкові, проміжні й кінцеві; безконфліктні та конфліктні ${ }^{1}$. Результати проведеного дослідження вказують на те, що вже на початковому етапі розслідування зазначених злочинів відомо особу, яка вчинила кримінальне правопорушення, оскільки заяви про вчинені злочини найчастіше надходять від державної виконавчої служби; окремих громадян і представників установ, організацій, права яких порушені. Ураховуючи викладене, пропонуємо на початковому етапі розслідування злочинів, що вчиняються службовими або іншими особами шляхом невиконання рішень органів правосуддя, виділити такі типові слідчі ситуації:

1. Особа, яка вчинила кримінальне правопорушення, переховується від органів досудового розслідування або чинить інші активні дії 3 протидії розслідуванню. Така ситуація характеризується як конфліктна й вимагає від слідчого значних зусиль щодо її вирішення.

2. Особа, яка вчинила злочин, визнала себе винною та сприяє його розслідуванню. Ця слідча ситуація характеризується найбільшим обсягом інформації щодо обставин злочину та відповідно є сприятливою для розслідування.

Слідчі ситуації, як правильно зазначається в криміналістичній літературі, зумовлюють основні напрями розслідування та прийняття слідчим відповідних рішень і обрання ним необхідного способу дії․ Розроблені алгоритми у свою чергу надають методичну допомогу слідчому, указують на шлях пошуку для одержання інформації та ефективного розслідування³

Аналіз судово-слідчої практики дозволяє виробити такий алгоритм дій слідчого в першій типовій слідчій ситуації під час розслідування злочинів, що вчиняються службовими або іншими особами шляхом невиконання рішень органів правосуддя:

— допит свідків (заявника; державних виконавців; осіб, які накладали арешт на майно; інших);

- витребування документів або тимчасовий доступ до них;

- огляд місця події (найчастіше ним є місцезнаходження предмета злочинного посягання);

— надання доручень оперативним підрозділам із метою встановлення місцезнаходження підозрюваного, місця переховування або збуту предмета злочинного посягання, установлення свідків);

- призначення судових експертиз.

${ }^{1}$ Див.: Драпкин Л. Я. Основы теории следственных ситуаций / Л. Я. Драпкин. Свердловск : Изд-во Урал. ун-та, 1987. - 165 с.; Белкин Р. С. Курс криминалистики : в 3 т. / Р. С. Белкин. - М. : Юристь, 1997. — Т. 3. - С. 143-144.

2 Див.: Малярова В. О. Розслідування злочинів проти моральності у сфері статевих стосунків: теорія та практика : монографія / В. О. Малярова ; за ред. С. М. Гусарова. - Х. : Диса плюс, 2013. - С. 222.

3 Див.: Щур Б. В. Теоретичні основи формування та застосування криміналістичних методик : монографія / Б. В. Щур. - Х. : Харків юрид., 2010. - С. 250. 
Алгоритм дій слідчого в другій ситуації такий:

— допит свідків (заявника; державних виконавців тощо);

- витребування або тимчасовий доступ до документів;

- допит підозрюваного;

— огляд місця події; свідків;

- надання доручень оперативним підрозділам із метою встановлення

- призначення судових експертиз.

Наступною особливістю розслідування злочинів, які вчиняються службовими або іншими особами шляхом невиконання рішень органів правосуддя, $\epsilon$ те, що слідчому необхідно вивчати низку документів, серед яких слід виділити:

- службову документацію органів, що здійснюють виконання судових рішень (або органів, які накладали арешт чи описували майно, тощо). Найчастіше такими документами $є$ рішення суду, матеріали виконавчого провадження, протоколи огляду описаного майна та ін.;

- посадові інструкції, накази про призначення на посаду, функціональні обов'язки. Зауважимо, що досліджувані злочини найчастіше вчиняють керівники органів місцевого самоврядування, керівники підприємств, установ, організацій, а тому перед слідчим постає питання - на кого конкретно був покладений обов'язок щодо виконання рішень органів правосуддя;

- довідки з Державного реєстру речових прав на нерухоме майно та з Єдиного реєстру заборони відчуження об'єктів нерухомого майна;

- бухгалтерську, банківську документацію (якщо предметом злочинного посягання були кошти як у готівковій, так і безготівковій формі);

- документи, що відображають господарську діяльність (ліцензії, договори тощо);

- довідки від різноманітних державних органів. Наприклад, за кримінальним провадженням, відкритим за ч. 1 ст. 382 КК України, 3 метою отримання інформації про факт відведення земельної ділянки та замовлення щодо неї проектної документації слідчому довелось звертатися до Київської державної адміністрації․․

Під час розслідування кримінальних проваджень щодо невиконання рішень органів правосуддя, як свідчить аналіз матеріалів судово-слідчої практики, невідкладною слідчою (розшуковою) дією є огляд місця події. Найчастіше по досліджуваним кримінальним правопорушенням місцем події є місцезнаходження предметів злочинного посягання (незнесені споруди, земельні ділянки, місця переховування арештованого майна або його складових тощо).

Слідчому необхідно встановити, які об'єкти знаходяться на місці події, визначити їх взаємне розташування та взаємозв'язок з іншими елементами обстановки, зафіксувати стан, комплектність, загальні та окремі ознаки об'єктів огляду. Потрібно також у протоколі зазначити факт охорони об'єкта,

${ }^{1}$ Див.: Архів Голосіївського районного суду м. Києва. Кримінальне провадження № 1-446/11. 
указуючи на засоби охорони (наявність паркану тощо). Нехтування цими правилами призводить до втрати важливих доказів.

Наступною особливістю розслідування зазначених злочинів $\epsilon$ те, що слідчому доводиться завжди проводити допит свідків й така слідча (розшукова) дія $є$ невідкладною. Коло свідків зазвичай досить широке, тому пропонуємо їх поділити на такі групи:

1) працівники Державної виконавчої служби. Слідчий при їх допиті може одержати криміналістично значущу інформацію про:

— час відкриття виконавчого провадження;

— виявлені ними порушення законодавства, що регулює порядок виконання рішень органів правосуддя;

- обставини вчинення злочину;

— осіб, винних або причетних до його вчинення;

— наслідки злочину;

- причини та умови, які сприяли вчиненню злочину тощо.

Так, за кримінальним провадженням за ч. 1 ст. 382 КК України, відкритим стосовно С. за умисне невиконання рішення суду як свідок був допитаний державний виконавець, під час допиту якого слідчий встановив: коли було відкрите виконавче провадження, які дії виконував державний виконавець 3 виявлення та встановлення місцезнаходження майна С., чи накладався арешт на майно, чи 3'являвся С. на виклики державного виконавця ${ }^{1}$;

2) очевидці невиконання рішень органів правосуддя. Ними можуть бути як працівники підприємства, установи, організації, де не виконувалося рішення органу правосуддя (юристи, працівники відділу кадрів, бухгалтерські працівники), так й інші особи (наприклад, свідки продажу предмета злочинного посягання). У ході допиту цих осіб слідчий з'ясовує: коли й за яких умов вони спостерігали невиконання рішення органу правосуддя (перешкоджання поновленню на роботі незаконно звільненого, приватизації майна, користуванню житлом, іншим майном; неповернення дитини); чи знали вони про незаконність дій; причини та умови, які сприяли вчиненню злочину тощо;

3) родичі підозрюваного. Ці особи можуть характеризувати підозрюваного, спосіб його життя, зв'язки.

Слід зазначити, що розслідування зазначених злочинів практично неможливе без проведення судових експертиз. Найчастіше призначаються товарознавчі, почеркознавчі експертизи. Товарознавчі експертизи призначаються $з$ метою визначення вартості предмета злочинного посягання. Почеркознавчі експертизи проводяться в разі необхідності ідентифікації особи за почерком. Також за таким кримінальним провадженням можуть проводитися дактилоскопічні, трасологічні експертизи.

Крім того, під час розслідування невиконання рішень органів правосуддя слідчому доводиться використовувати допомогу оперативних підрозділів, адже, як правильно відмічено в криміналістичній літературі, ефективність протидії злочинності значною мірою залежить від згуртованості

1 Див.: Архів Бабушкінського районного суду міста Дніпропетровськ. Кримінальне провадження 200/8684/14-к1-кп/200/427/14. 
правоохоронних органів, зближення різних напрямів їх функціонування ${ }^{1}$. Це дає можливість слідчому своєчасно приймати необхідні процесуальні й тактичні рішення, отримувати як орієнтуючу, так і доказову інформацію. Найчастіше слідчий звертається до оперативних підрозділів із метою встановлення місцезнаходження підозрюваного, предмета злочинного посягання, виявлення свідків злочину.

Підсумовуючи викладене, зазначимо, що на початковому етапі розслідування злочинів, які вчиняються службовими або іншими особами шляхом невиконання рішень органів правосуддя, слідчому вже відома інформація про особу підозрюваного, а тому слід виділити такі типові слідчі ситуації: 1) особа, яка вчинила кримінальне правопорушення, переховується від органів досудового розслідування або чинить інші активні дії з протидії розслідуванню; 2) особа, яка вчинила злочин, визнала себе винною та сприяє його розслідуванню. Невідкладними слідчими (розшуковими) діями за таким кримінальним провадженням $є$ огляд місця події, допит свідків. Під час розслідування невиконання рішень органів правосуддя слідчому необхідно вилучати низку документів, призначати судові експертизи, використовувати допомогу оперативних підрозділів.

Перспективами подальших досліджень є розроблення засобів криміналістичної профілактики розглядуваних злочинів.

\title{
ОСОБЕННОСТИ РАССЛЕДОВАНИЯ ПРЕСТУПЛЕНИЙ, СОВЕРШАЕМЫХ ДОЛЖНОСТНЫМИ ИЛИ ДРУГИМИ ЛИЦАМИ ПУТЕМ НЕВЫПОЛНЕНИЯ РЕШЕНИЙ ОРГАНОВ ПРАВОСУДИЯ
}

\author{
Книженко С. $A$.
}

Определены основные особенности расследования преступлений, совершаемых должностными или иными лицами путем невыполнения решений органов правосудия. Раскрыты типичные следственные ситуачии первоначального этапа расследования таких преступлений, представлены алгоритмы действий следователя. Рассмотрены тактические особенности проведения отдельных следственных (розыскных) действий и вопросы взаимодействия следователя с правоохранительными органами.

Ключевые слова: неисполнение решений органов правосудия, преступления против правосудия, расследование преступлений, криминалистическая методика.

\section{FEATURES OF INVESTIGATION OF CRIMES COMMITTED BY OFFICIALS OR OTHER PERSONS BY MEANS OF NONCOMPLIANCE WITH JUDICIAL POWER DECISIONS}

\section{Knyzhenko S. O.}

The process of investigation of crimes committed by public officials or other persons by means of noncompliance with judicial power decisions is associated to obtaining, analysis and use of various types of the information contained in the documents. This causes

${ }^{1}$ Див.: Топчій B. Принципи взаємодії слідчого й оперативного працівника органів внутрішніх справ при розкритті та розслідуванні злочинів / В. Топчій // Підприємництво, госп. і право. - 2015. - № 3. - С. 71-75. 
the necessity of searching new criminalistical approaches regarding the acceptance, analysis and use of the documents in the course of evidence during the pre-trial investigation of the indicated crimes. The paper analyzes scientific works devoted to the problems of specific kinds of crimes against justice investigation. On their basis, as well as on the analysis of materials of investigative and judicial practice there are defined the main features of their investigation. The author is identified the following typical investigative situations of the initial stage of such crimes inquiry: 1) a person, who is committed a crime, is hiding from the pre-trial investigation bodies, or he commits other active actions to counter the investigation. This situation is characterized as a conflict and requires considerable efforts to overcome it from the investigator; 2) crime committer pleaded guilty and contributes to its inquiry. This investigative situation is characterized by the largest amount of information on the circumstances of the crime and, accordingly, it is favorable for the inquiry. On the suggested typical investigative situations of the initial stage of such crimes inquiry there are presented an algorithms of investigator actions. Tactical features of crime scene investigation, questioning of witnesses are considered. Forensic examinations which are most commonly scheduled in investigating these crimes are indicated. There are defined the subjects of interaction and the problems of an investigator interaction with law enforcement bodies.

Keywords: noncompliance with judicial power decisions, crimes against justice, crime investigation, criminalistic technique.

УДК 343.98

C. В. Веліканов, доцент кафедри криміналістики Національного юридична університету імені Ярослава Мудрого, кандидат юридичних наук, доцент

\section{ЧАСОВА ОЗНАКА ПРИЧИННО-НАСЛІДКОВОГО ЗВ'ЯЗКУ В КРИМІНАЛІСТИЦІ}

Розглянуто питання часової ознаки причинно-наслідкового зв'язку в криміналістиці. Опрацьовано проблематику асиметрії напрямку часу та причинності, запропоновано підходи до з'ясування послідовності й одночасності подї̈-причини та подї̈-наслідку в криміналістиці.

Ключові слова: асиметрія причинно-наслідкового зв'язку, асиметрія часового відношення, послідовність події-причини та події-наслідку, часова ознака причинно-наслідкового зв'язку.

Час як обставина вчинення кримінального правопорушення, відповідно до ст. 91 Кримінального процесуального кодексу України, підлягає доказуванню в кримінальному провадженні. Такий нормативний припис зумовлює обов'язковість установлення моментів виникнення й завершення, періоду тривання конкретної події, так само як і часового співвідношення декількох подій у криміналістичному дослідженні причинно-наслідкового зв’язку. Створені для роботи з часом засоби та рекомендації криміналістичної техніки, тактики й методики розслідування базуються на повсякденних і надзвичайно ригідних, постійно підтверджуваних практикою, інтуїціях проб-

(C) Веліканов С. В., 2016 